\title{
The Study In Vitro of the Effects of the Inhalant Corticosteroids on Oral and Laryngeal Mucosa
}

Menicagli Roberto and Marotta Ortensio*

Senior Researcher in Biochemistry, Roma Biomed Research, Martiri Libertà 6/a 20060 Mediglia, Italy

\begin{abstract}
Background: The pharmacology activity of corticosteroids, is due to the formation in the blood of the complex Corticosteroid- Protein Glycosylated, that, in this form, after the binding to the cytoplasmic receptor, penetrates in the target cells. This interaction process, also happens, with salivary proteins The aim of this study is, to study this process, that precipitate the salivary proteins, and with them, the salivary secreted mucin.

Materials and methods: In two samples of whole saliva provided by volunteers, are added different concentrations of three corticosteroids, beclometasone, budesonide, fluticasone. The samples are centrifuged, and in surnatant, dosed, the amounts of total salivary proteins and mucins. The results are statistically analyzed with Mann Whitney U Test, Test T, Pearson Correlation Coefficient

Results and discussion: With all dosage, the difference of the proteins and mucins precipitated by the Budesonide, and beclometasone vs fluticasone, are statistically different., $p \leq 0.05$. For all three corticosteroids, there is a saturation value, with a good correlation between corticosteroids's dosage and the amount of the proteinmucins precipitation, (Pearson coefficient of 0.91). The little difference in the precipitation of the mucins, and the proteins, $p=0.0334$, obtained with the budesonide versus beclometasone, can find an explanation, for the presence in the first, of two hydroxyl groups, (one in beclometasone). The difference of beclometasone and budesonide, versus fluticasone, is due assuming that the parameters, that stabilize the (CCP), type hydrogen bonds and Van der Waals forces, are more influenced by solubility in water, there is nothing for the fluticasone, rather than by the chemical conformation of drugs
\end{abstract}

Keywords: Corticosteroid; Aerosol; Precipitation; Proteins; Salivary mucins

\section{Introduction}

For its anti-inflammatory properties, cortisone medications are used successfully in the treatment of respiratory diseases such as asthma, pulmonary fibrosis. The pharmacology of corticosteroids is very complex, but can be summed up with the explication of these activities:

1. Interaction and complex formation Corticosteroid- Protein Glycosylated (GR) - (CCP)

2. Transport inactivated form of (CCP) to the target cells

3. Penetration (CCP) in the cells and binding to the cytoplasmic receptor

4. Anti-inflammatory corticosteroid activity: the complex (CCP. penetrates into the nucleus and interacts with the DNA activating or inhibiting gene transcription, responsible of the major pharmacological effects of corticosteroids. The complex, in addition, is able to block the way of NFkB (nuclear factor kappalight-enhance of activated B cells, the key of many mechanisms in inflammatory and immunological diseases). In those passages, the formation of a "Protein-Corticosteroid" complex, that allows the transport of corticosteroids, have a key rule

In the blood, this training, involving approximately eighty percent of the concentration of the corticosteroid, is between the same (position C19 and C23), and a protein that is a non-inhibitory member of the serine proteinase inhibitor (serpin) super-family, and have high-affinity transport protein for corticosteroids in blood. plasma. CBG is a glycoprotein with $30 \%$ of its mass represented by $\mathrm{N}$-linked oligosaccharide chains (Chuang C K.2. Recent crystal structure analyses of intact rat $\mathrm{CBG}$ and cleaved human $\mathrm{CBG}$ have revealed the precise topography of the steroid-binding site, and shown that cortisolbound CBG displays a typical stressed (S) serpin conformation with the Reactive Center Loop (RCL) fully exposed from the central betasheet [1-4]. Corticosteroids can also pair with other proteins and their affinities can vary greatly [5]. In function of many parameters, these bonding mechanisms have been studied in order to understand both the anti-inflammatory capacity of cortisone is some of the possible side effects of these drugs. These variations actually depend not only on the type of chemical structure of cortisone compounds, but as it has been shown recently also, and perhaps more than that of proteins. In particular may occur naturally or not, modifications/alterations in the glycosylation process of the serum proteins, which involves a variation in the percentage of the carbohydrate part [6-12]. These changes modify the protein folding in a definitive way with consequences both in terms of possible catalytic activities of proteins. Both in the processes of interaction of the same, with different substrates as it is clear that the process and interaction / binding between proteins and corticosteroids easily occurs in the blood. with the formation of a stable complex, that reasonably can also happen in the saliva. In this medium, also are not present globulins, which in the blood have the highest affinity with the corticosteroids, and therefore they can bind with the various proteins present. This fact could change their functionality and their role, that

*Corresponding author: Marotta Ortensio, Senior Researcher in Biochemistry, Roma Biomed Research, Martiri Libertà 6/a 20060 Mediglia, Italy, E-mail: menicagli@libero.it

Received May 15, 2017; Accepted May 20, 2017; Published May 25, 2017

Citation: Roberto M, Ortensio M (2017) The Study In Vitro of the Effects of the Inhalant Corticosteroids on Oral and Laryngeal Mucosa. Med Chem (Los Angeles) 7: 884-889. doi: 10.4172/2161-0444.1000447

Copyright: ( $) 2017$ Roberto M, et al. This is an open-access article distributed under the terms of the Creative Commons Attribution License, which permits unrestricted use, distribution, and reproduction in any medium, provided the original author and source are credited. 
is critical to the defences of the oral cavity and larynx. In a precedent study, we have showed, as the interaction salivary proteins with two different corticosteroids, used as inhalant drugs, in asthmatic people, interacting with salivary proteins, they may precipitate an amount that at therapeutic doses, reached about 20. Therefore, salivary proteindrug interactions play a key role in pharmacokinetics and pharmacodynamics of the drugs. And In particular mucin-drug interaction may have important effects on the drug absorption, (mucus is the first barrier that drugs must overcome to be adsorbed and gain access to the circulatory system) and distribution, (only the free concentration of drug can get to the target and produce a biological response). This means that a high binding may reduce the drug's pharmaceutical effect.

Beyond the types of nebulizers used in aerosol therapy, it must be emphasized that it is not associated only in the winter season and with colds, but also the spring and allergic phenomena, which occur more and more numerous in this season. Therefore the constant use of corticosteroids may lead to increased side effects because of the latter, they should be used with caution. Corticosteroid drugs often inhale can lead to hoarseness, with atrophy of the vocal cords, fungal lesions, and xerostomia. The hypothesis is that, these interactions, involve the most important proteic components of the oral mucus, the salivary secreted mucins, MUC 7 and MUC5B, Since mucus acts as a barrier, there are two main mechanisms that limit diffusion through mucus gel: (a) interaction with mucus components (i.e., electrostatic and hydrophobic interactions with mucins), and (b) size filtering related to the size of the mesh spacing between mucin fibers. Many studies highlighted that no definitive picture of the nature of the molecular interactions between drug molecules and the mucin components can be drawn.. this mechanism, has already been clarified in part, in a qualitative way, by means of spectrophotometric studies, UV-Vis spectroscopy showed that, the prednisolone drug, can bind to mucin to form a protein-drug complex. Fluorescence data proved that mucin fluorescence can be quenched by the studied drug and that the quenching is governed by a dynamic quenching for mucin and interaction. with prednisolone, with the occurrence, according to thermodynamic parameters, with hydrophobic, hydrogen bonds and van der Waals forces, that may play a major role in stabilizing mucin-prednisolone and mucin-complexes. Purpose of this our study, is to obtain quantitative data, of these interaction processes., verifying, possible differences between different corticosteroids ee possibly between the total salivary proteins, and the mucin fraction, based on the quantity precipitated

\section{Materials and Methods}

The whole saliva samples, $10 \mathrm{ml}$, were provided by a male volunteer aged 30 years, who are not smoking, not denounced cardiovascular diseases the amounts of the samples of saliva are those produced in an average time it takes for one cycle of the aerosol therapy. In saliva samples before and after the addition of corticosteroids, were determined the concentrations of the total protein by the Biuret test at, the $\mathrm{pH}$ with digital $\mathrm{ECO}$, while for the dosage of total salivary mucins are used the Alcian Blue.

\section{Method}

Three samples of corticosteroids, are been used, and their commercial properties are as follow:

1. Beclomethasone dipropionate: $0.8 \mathrm{mg} / 2 \mathrm{ml}$ suspension to be nebulized aerosol

Single-dose vials of $2 \mathrm{ml}$ aerosol Composition $100 \mathrm{ml}$ of sterile suspension containing:
Active ingredient: beclomethasone dipropionate $0.040 \mathrm{~g}$. Excipients: Sodium chloride; Polysorbate 20; Sorbitan monolaurate; Water for injections:

1. Budesonide $0.5 \mathrm{mg} / \mathrm{ml}$ suspension nebulizer 1 single dose container contains: Active ingredient: $1 \mathrm{mg}$ busedonide

2. Fluticasone Inhalation Powder 100, 250 and 500 micrograms of fluticasone propionate pressurized inhalation, suspension from $50,125,250 \mathrm{mcg}$ of fluticasone propionate.

After the addition of corticosteroids, to saliva, the same samples were subjected to centrifugation a $4000 \mathrm{rpm}$ for two minutes, In the surnatant were determined by the methods mentioned above, the total mucin and the total proteins. The results are statistically analyzed with Mann-Whitney U Test, and Pearson Correlation Coefficient. The Mann-Whitney U Test is a nonparametric test that allows two groups or conditions to be compared without making the assumption that values are normally disturbed.

Requirement: the data is continuous, scale of measurement should be ordinal, interval of ratio Pearson Correlation Coefficient is used to measure the strength of a linear association between two variables, where the value $r=1$ means a perfect positive correlation and the value $\mathrm{r}=-1$ means a perfect. The results for the difference of the precipitation of the mucins by the three corticosteroids are statistically analyzed, with $\mathrm{T}$ Test, two-tailed, in identical variance

\section{Results}

In the first three tables, are showed, the results of the amount of total salivary protein and mucin precipitated, in function of each single corticosteroid, while in Table 4 are indicated only the differences relating to mucins, only to highlight the average value of their precipitation as a function the average concentration of corticosteroid used (Table 1).

\section{Results of statistical analysis}

Mann-Whitney $\mathbf{u}$ test for beclometasone: Total proteins $v s$ total mucins.

The $\mathrm{U}$-value is 59.5 . The critical value of $\mathrm{U}$ at $\mathrm{p}<0.05$ is 45 . Therefore, the result is not significant at $\mathrm{p}<0.05$.

The Z-Score is -1.23443 . The $\mathrm{p}$-value is 0.2187 . The result is not significant at $\mathrm{p}<0.05$ (Scheme 1 and Table 2).

\section{Results of statistical analysis}

Mann-Whitney u test for budesonide: Total proteins $v s$ total mucins.

The $\mathrm{U}$-value is 58 . The critical value of $\mathrm{U}$ at $\mathrm{p}<0.05$ is 37 . Therefore, the result is not significant at $\mathrm{p}<0.05$.

The Z-Score is -0.77942 . The $\mathrm{p}$-value is 0.4354 . The result is not significant at $\mathrm{p}<0.05$ (Scheme 2 and Table 3 ).

\section{Results of statistical analysis}

Mann-Whitney u test for fluticasone: Total proteins $v s$ total mucins.

The $\mathrm{U}$-value is 68 . The critical value of $\mathrm{U}$ at $\mathrm{p}<0.05$ is 37 . Therefore, the result is not significant at $\mathrm{p}<0.05$.

The Z-Score is -0.20207 . The p-value is 0.84148 . The result is not significant at $\mathrm{p}<0.05$. 
Citation: Roberto M, Ortensio M (2017) The Study In Vitro of the Effects of the Inhalant Corticosteroids on Oral and Laryngeal Mucosa. Med Chem (Los Angeles) 7: 884-889. doi: 10.4172/2161-0444.1000447

\begin{tabular}{|c|c|c|c|c|c|}
\hline \multirow[t]{2}{*}{$\begin{array}{c}\text { Corticosteroid } \\
\text { Beclometasone } \mathrm{mg}\end{array}$} & \multicolumn{2}{|c|}{$\begin{array}{l}\text { Total Salivary Protein S Initial concentration in saliva } \\
\qquad \mathrm{mg} / \mathrm{dL}=33\end{array}$} & \multicolumn{2}{|c|}{$\begin{array}{l}\text { Total Salivary Mucins Initial concentration in saliva } \\
\mathrm{mg} / \mathrm{dL}=50\end{array}$} & \multirow[t]{2}{*}{ Saliva cc } \\
\hline & Proteins in surnatant $\mathrm{mg} / \mathrm{dL}$ & $\%$ precipitation & Mucins in surnatant $\mathrm{mg} / \mathrm{dL}$ & $\%$ precipitation & \\
\hline 0 & 31.4 .1 & 5 & 4.8 & 4 & 10 \\
\hline 0.2 & 31 & 6.1 & 4.7 & 6 & 10 \\
\hline 0.5 & 30 & 9.1 & 4.5 & 10 & 10 \\
\hline 0.8 & 28 & 15.2 & 4.2 & 13 & 10 \\
\hline 1 & 26 & 21,2 & 4 & 17 & 10 \\
\hline 1.2 & 25.5 & 22.7 & 3.8 & 21 & 10 \\
\hline 1.4 & 25 & 24,4 & 3.7 & 24 & 10 \\
\hline 1.6 & 24.8 & 24.8 & 3.6 & 26 & 10 \\
\hline 1.8 & 24 & 27.2 & 3.5 & 28 & 10 \\
\hline 2 & 24 & 27.2 & 3.5 & 29 & 10 \\
\hline 2.5 & 24 & 27.2 & 3.5 & 30 & 10 \\
\hline 3 & 24 & 27.2 & 3.5 & 30 & 10 \\
\hline
\end{tabular}

Table 1: Addition of Beclometasone and precipitation percentage of proteins and salivary mucins.

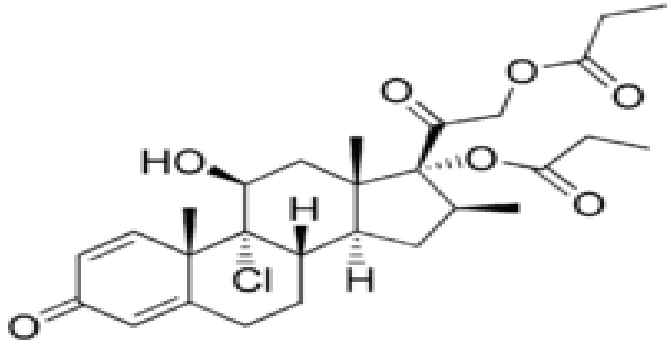

Scheme 1: Beclometasone chemical structure.

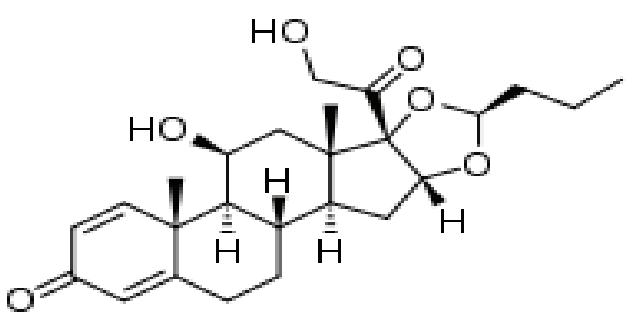

Scheme 2: Budesunide chemical structure.

\begin{tabular}{|c|c|c|c|c|c|}
\hline \multirow[t]{2}{*}{$\begin{array}{l}\text { Corticosteroid } \\
\text { Budesonide } \mathrm{mg}\end{array}$} & \multicolumn{2}{|c|}{$\begin{array}{l}\text { Total Salivary Protein S Initial concentration in saliva } \\
\qquad \mathrm{mg} / \mathrm{dL}=35\end{array}$} & \multicolumn{2}{|c|}{$\begin{array}{l}\text { Total Salivary Mucins Initial concentration in saliva } \mathrm{mg} / \\
\qquad \mathrm{dL}=5\end{array}$} & \multirow[t]{2}{*}{ Saliva cc } \\
\hline & Proteins in surnatant $\mathrm{mg} / \mathrm{dL}$ & $\%$ precipitation & Mucins in surnatant $\mathrm{mg} / \mathrm{dL}$ & $\%$ precipitation & \\
\hline 0.1 & 34 & 3 & 4.8 & 4 & 10 \\
\hline 0.2 & 33 & 5.7 & 4.7 & 6 & 10 \\
\hline 0.5 & 31 & 13.4 & 4.6 & 12 & 10 \\
\hline 0.8 & 29 & 18.9 & 4.3 & 17 & 10 \\
\hline 1 & 28 & 22,2 & 4.1 & 20 & 10 \\
\hline 1.2 & 27 & 23.7 & 3.8 & 24 & 10 \\
\hline 1.4 & 25 & 25,4 & 3.7 & 26 & 10 \\
\hline 1.6 & 24 & 26.8 & 3.6 & 28 & 10 \\
\hline 1.8 & 24 & 27.2 & 3.5 & 30 & 10 \\
\hline 2 & 24 & 27.2 & 3.5 & 30 & 10 \\
\hline 2.5 & 24 & 27.2 & 3.5 & 30 & 10 \\
\hline 3 & 24 & 27.2 & 3.5 & 30 & 10 \\
\hline
\end{tabular}

Table 2: Addition of Budesonide and precipitation percentage of proteins and salivary mucins.

\begin{tabular}{|c|c|c|c|c|c|}
\hline \multirow[t]{2}{*}{$\begin{array}{c}\text { Corticosteroid Fluticasone } \\
\text { mg }\end{array}$} & \multicolumn{2}{|c|}{$\begin{array}{l}\text { Total Salivary Protein S Initial concentration in saliva } \\
\qquad \mathrm{mg} / \mathrm{dL}=35\end{array}$} & \multicolumn{2}{|c|}{$\begin{array}{l}\text { Total Salivary Mucins Initial concentration in saliva mg/ } \\
\qquad \mathrm{dL}=5\end{array}$} & \multirow[t]{2}{*}{ Saliva cc } \\
\hline & Proteins in surnatant $\mathrm{mg} / \mathrm{dL}$ & $\%$ precipitation & Mucins in surnatant $\mathrm{mg} / \mathrm{dL}$ & $\%$ precipitation & \\
\hline 0.1 & 35 & 0 & 5 & 0 & 10 \\
\hline 0.2 & 34,3 & 1 & 5 & 0 & 10 \\
\hline 0.5 & 34,2 & 2 & 4.9 & 3 & 10 \\
\hline 0.8 & 33.6 & 4 & 4.8 & 5 & 10 \\
\hline 1 & $33 . .5$ & 4 & .4 .7 & 6 & 10 \\
\hline 1.2 & 32.5 & 8 & 4.7 & 6 & 10 \\
\hline 1.4 & 31.9 & 9 & 4.5 & 10 & 10 \\
\hline 1.6 & 31.5 & 10 & 4.5 & 10 & 10 \\
\hline 1.8 & 31.5 & 10 & 4.5 & 10 & 10 \\
\hline 2 & 31.5 & 10 & 4.5 & 10 & 10 \\
\hline 2.5 & 31.5 & 10 & 4.5 & 10 & 10 \\
\hline 3 & 31.5 & 10 & 4.5 & 10 & 10 \\
\hline
\end{tabular}

Table 3: Addition of fluticasone and precipitation percentage of proteins and salivary mucins. 
The $\mathrm{U}$-value is 68 . The critical value of $\mathrm{U}$ at $\mathrm{p}<0.05$ is 37 . Therefore, the result is not significant at $\mathrm{p}<0.05$ (Scheme 3 and Table 4 ).

Test $\mathrm{T}$ for budesonide $v$ s beclometason; $\mathrm{p}=0.334 ; \mathrm{p} \geq 0.05$

Test $\mathrm{T}$ for beclometasone $v$ f fluticasone; The $\mathrm{t}$-value is -3.52189 . The $\mathrm{p}$-value is 0.003385 . The result is significant at $\mathrm{p}<0.05$.

Test $\mathrm{T}$ for Budesonide $v$ f fluticasone; The $\mathrm{t}$-value is -3.79393 . The $\mathrm{p}$-value is 0.000882 . The result is significant at $\mathrm{p}<0.05$.

Pearson correlation coefficient $\mathrm{mg}$ beclometasone $v s \%$ mucins Precipitation.

The value of $\mathrm{R}$ is 0.940 . This is a strong positive correlation, which means that high $\mathrm{X}$ variable scores go with high $\mathrm{Y}$ variable scores (and vice versa).

Pearson correlation coefficient mg Budesonide vs \% mucins Precipitation: The value of $\mathrm{R}$ is 0.904 . This is a strong positive correlation, which means that high $\mathrm{X}$ variable scores go with high $\mathrm{Y}$ variable scores (and vice versa).

Pearson correlation coefficient mg fluticasone vs \% mucins Precipitation.

The value of $\mathrm{R}$ is 0.8912 . This is a strong positive correlation, which means that high $\mathrm{X}$ variable scores go with high $\mathrm{Y}$ variable scores (and vice versa) (Figures 1-3).

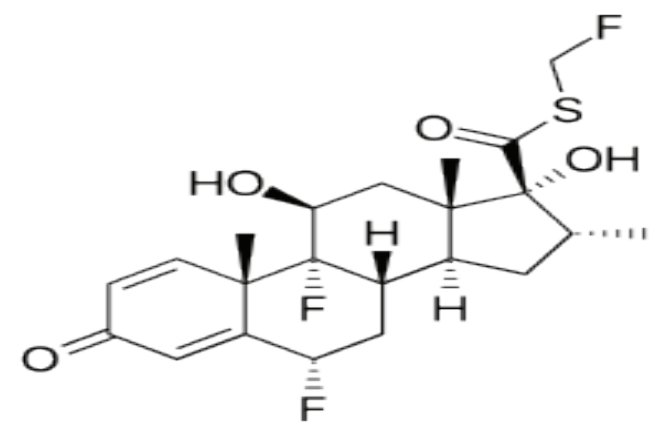

Scheme 3: Fluticasone chemical structure.

\begin{tabular}{|c|c|c|c|c|c|}
\hline \multicolumn{2}{|c|}{ Beclometasone } & \multicolumn{2}{|c|}{ Butesomide } & \multicolumn{2}{|c|}{ Fluticasone } \\
\hline mg & $\begin{array}{c}\% \\
\text { Precipitation } \\
\text { mucins }\end{array}$ & $\mathrm{mg}$ & $\begin{array}{c}\% \\
\text { Precipitation } \\
\text { mucins }\end{array}$ & $\mathrm{mg}$ & $\begin{array}{c}\% \\
\begin{array}{c}\text { Precipitation } \\
\text { mucins }\end{array}\end{array}$ \\
\hline 0.1 & 4 & 0.1 & 4 & 0.1 & 0 \\
\hline 0.2 & 6 & 0.2 & 6 & 0.2 & 1 \\
\hline 0.5 & 10 & 0.5 & 12 & 0.5 & 2 \\
\hline 0.8 & 13 & 0.8 & 16.5 & 0.8 & 4 \\
\hline 1 & 17 & 1 & 20 & 1.0 & 4 \\
\hline 1.2 & 21 & 1.2 & 24 & 1.2 & 8 \\
\hline 1.4 & 24 & 1.4 & 26 & 1.4 & 9 \\
\hline 1.6 & 26 & 1.6 & 28 & 1.6 & 10 \\
\hline 1.8 & 28 & 1.8 & 30 & 1.8 & 10 \\
\hline 2.0 & 29 & 2.0 & 30 & 2.0 & 10 \\
\hline 2.5 & 30 & 2.5 & 30 & 2.5 & 10 \\
\hline 3.0 & 30 & 3.0 & 30 & 3.0 & 10 \\
\hline $\begin{array}{l}\text { Average } \\
\mathrm{mg} 13.4\end{array}$ & $\begin{array}{c}\text { Average of } \\
\text { Precipitation } \\
19.8 \%\end{array}$ & $\begin{array}{c}\text { Average mg } \\
13.4\end{array}$ & $\begin{array}{c}\text { Average of } \\
\text { Precipitation } \\
21.5 \%\end{array}$ & $\begin{array}{l}\text { Average } \\
\text { mg } 13.4\end{array}$ & $\begin{array}{c}\text { Average of } \\
\text { Precipitation } \\
5.8 \%\end{array}$ \\
\hline
\end{tabular}

Table 4: Addition of the corticosteroids and precipitation percentage of salivary mucins.

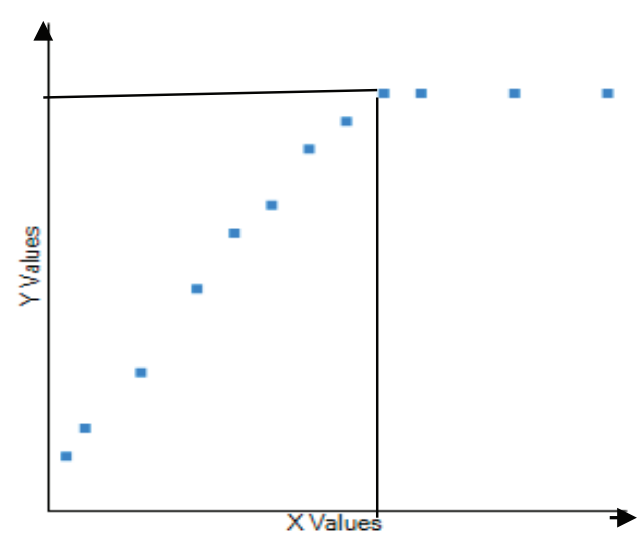

Figure 1: Beclometasone correlation test.

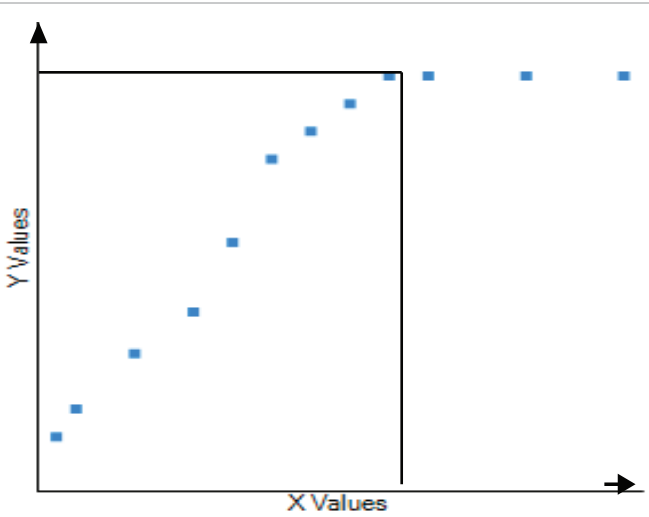

Figure 2: Budesonide correlation test.

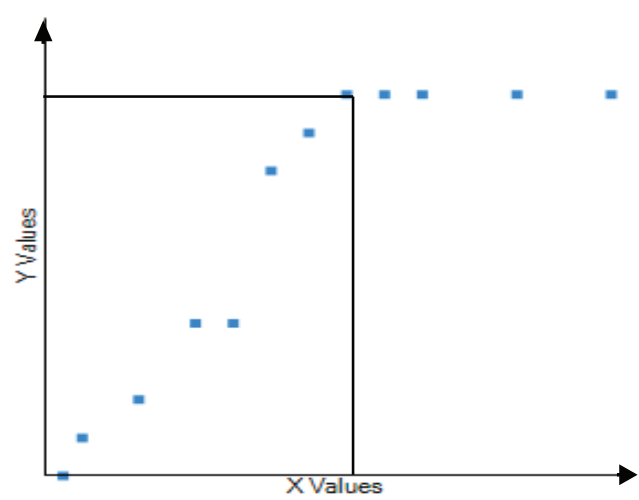

Figure 3: Fluticasone correlation test.

\section{Discussion}

The above results, in relation to total salivary proteins, confirm the results of our previous study [7], although the amount of proteins precipitated by beclometasone and Budesonide is lower. As far as the protein fraction of mucins is concerned [10], where patients treated with high doses of Inhaled Corticosteroids showed lower levels of salivary MUC5B compared with those treated with medium Inhaled Corticosteroids doses or those not treated. In this study, experimentally, compared to the our previous research, the corticosteroid after its 


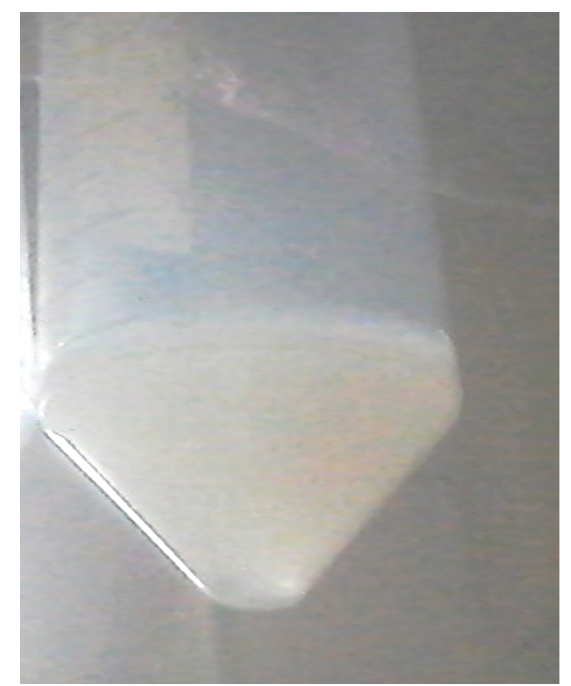

Figure 4: Initial formation of the corticosteroid- protein complex.

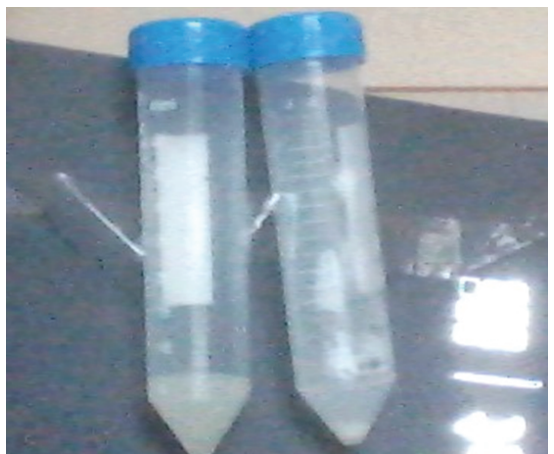

Figure 5: The precitation and the separation of the complex.

addition to saliva, after its addition to saliva, was highly dispersed with a micro vibrator, rather than leaving the complex to slowly sediment alone :So after, this process, the suspension that is obtained, see Figure 4, it was centrifuged for two minutes at $4000 \mathrm{rpm}$ and not allowed to decant, thus obtaining a surnatant. absolutely clear see Figure 5. Notably, precisely, in reference to the previous results, that this time, there is a little difference in the amount of salivary proteins precipitated, and this difference, it is due to the addition of Budesonide, rather than to Blecometasone. In any case, the differences, for the three corticosteroids, have a constant trend, see Tables 1 and 2, for all added amounts of corticosteroidsThese results, however, can be to find a logical explanation, admitting that the main forces that govern the interaction process leading to the formation and stabilization of Protein-corticostiroid complex, are the hydrogen bonds, hydrophobic interactions, and van der Waals forces. Theese may play a major role in stabilizing proteins -corticosteroid complex, as happen, for example, when are added in saliva the polyphenol compounds, with the result, that also in small concentration of the same, there is the total proteins precipitation. In this case a fundamental rule is two to the Hydrogen bonds that are established between the hydroxyl groups $(\mathrm{OH})$ of polyphenols and the carbonyl $(\mathrm{C}=\mathrm{O})$, of the amino acids of proteins.

In Budesonide in fact there are two hydroxyl groups, one only in beclomethasone, see figures and equal solubility in an aqueous

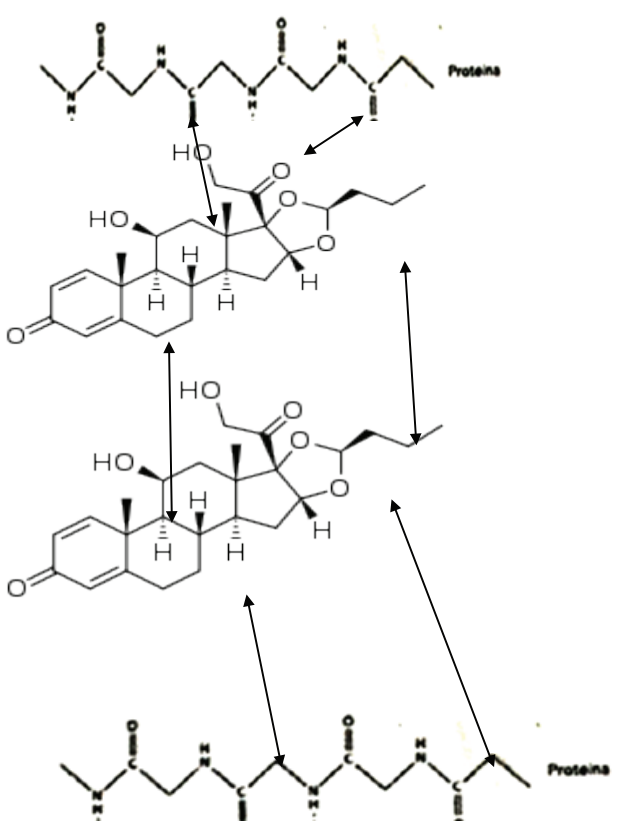

Figure 6: The formation of the complex protein mucin corticosteroid.

environment, which is still very low, this fact may justify the results of Tables 1, 2 and 4. The precipitation data, detect very low concentration both in the precipitation of cghe protine of mucins, with statistically significant differences compared to that sial Budesonide Beclomethasone, and this depends on practically insolubility of this corticosteroid in an aqueous environment. All factors mentioned above, make that the corticosteroids compounds can easily interact with the proteins And Also with the mucins by setting the characteristic of the colloidal structure See Figures. These structures take the form of polymers dispersed in saliva, with the physical properties of colloids and in Particular their stability in the dispersing phase, in our case the saliva, depend on the electrical double layer That characterizes the protein of the double layer interface, or generated by the electrical potential, called Z. The potential formation of links between a single corticosteroid molecule and a protein colloidal particle deforms the latter structure, change the interface of the double layer, changing the $\mathrm{Z}$ potential and it has the precipitation. The results expressed in Tables $1-3$, also show that there are no statistically significant differences in the amounts of precipitated proteins, compared to mucins, and this indicates that the glycosylated part of the same, is irrelevant in, probably because the interaction processes structure sugary, subtracts water to the system, with a solvation process that tends to isolate the protein part (Figure 6).

\section{Conclusion}

This fact, together with the low solubility of corticosteroids, almost nothing for fluticasone, the system leads to a quick saturation, practically for a $1.6 \mathrm{mg}$ dosage, as you can see from the figures and from the respective tables.

\section{References}

1. Gardill BR, Vogl MR, Lin HY, Hammond GL, Muller YA (2012) Corticosteroidbinding globulin: structure-function implications from species differences. PloS ONE 7: e52759.

2. Chuang CK, Lin HY, Wang TJ, Tsai CC, Liu HL, et al. (2014) A modified liquid chromatography/tandem mass spectrometry method for predominant 
Citation: Roberto M, Ortensio M (2017) The Study In Vitro of the Effects of the Inhalant Corticosteroids on Oral and Laryngeal Mucosa. Med Chem (Los Angeles) 7: 884-889. doi: 10.4172/2161-0444.1000447

disaccharide units of urinary glycosaminoglycans in patients with mucopolysaccharidoses. Orphanet J Rare Dis 9:135

3. Gibbins HL, Proctor GB, Yakubov GE, Wilson S, Carpenter GH (2014) Concentration of salivary protective proteins within the bound oral mucosal pellicle. Oral diseases 20: 707-713.

4. Mickelson KE, Forsthoefel J, Westphal U (1981) Steroid-protein interactions. Human corticosteroid binding globulin: some physicochemical properties and binding specificity. Biochemistry 20: 6211-6218.

5. Westphal U (1978) Steroids - Proteins Interaction. ISBN-13-78- 978. SpringerVerlag.

6. Avvakumov GV, Grishkovskaya I, Muller YA, Hammond GL (2002) Crystal structure of human sex hormone-binding globulin in complex with 2-methoxyestradiol reveals the molecular basis for high affinity interactions with C-2 derivatives of estradiol. J Biol Chem 277: 45219-45225.

7. Ali S, Bassett JR (1995) Studies on the role of glycosylation in the origin of the electrophoretic variants for rat corticosteroid-binding globulin. Steroids 60 743-752.

8. Menicagli R, Duca M, Arizzi C (2016) Merit Journ Resech 4: 127-132.

9. Pontremoli C, Barbero N, Viscardi G, Visentin S (2015) Mucin-drugs interaction: the case of theophylline, prednisolone and cephalexin. Biorg Med Chem 23: 6581-6586.

10. Navarrete BA, Palacios PJ, Aguilar-Salvatierra A, Guardia J, Gómez-Moreno G (2015) Effects of inhalated corticosteroids on saliva composition: a cross sectional study in patient with bronchial asthma. Clin Drug Investig 35: 569-574.

11. Menicagli R, Duca M, Rancoita PMV (2016) Traditional Food Habits and their Possible Relationship in Diseases of the Mouth: The Use of Paprika. MR Journal, pp: 1-7.

12. Menicagli R, Duca M, Rancoita PMV, Arizzi CE (2016) The influence of the mucins in genetic balance in oral and laryngeal cancer and by their biochemical behaviour a working hypothesis for their care. International Journal of Current Research 8: 29800-29806. 